\title{
INTERCULTURAL DIALOGUE AND INTERGROUP RELATIONS IN EUROPE: CONTRIBUTIONS OF Cultural Studies and Social Psychology
}

\author{
Julia Alves Brasil \& Rosa Cabecinhas
}

\begin{abstract}
This paper discusses the contributions of Cultural Studies and Social Psychology to the debates on the challenges inherent to the promotion of intercultural dialogue in Europe, in the current context of intergroup relations among several Others, facilitated by factors such as the intensification of migratory flows and the enhancement of information and communication technologies. To this end, we associate concepts and categories from different theoretical perspectives in these fields, in order to articulate discussions about identity processes, alterity, social representations, collective memory, symbolic asymmetries, coloniality of power, being and knowledge, to (re)initiate debates on complex phenomena that are intertwined in the development of intercultural dialogue. Therefore, different understandings about the concepts of multiculturalism and interculturality are presented, advocating the importance of a critical perspective in the understanding of interculturality, conceiving it as a project that starts from the experiences of the "subalterns", in order to seek the transformation of social, institutional and epistemic structures. This perspective allows people to (re)create different ways of being and relating to others, implying not only the mere recognition and tolerance of other cultures, but also their appreciation, in mutual dialogue and transformation.
\end{abstract}

KEYWORDS

Intercultural dialogue; Cultural Studies; Social Psychology; intergroup relations

\section{DIÁLOGO INTERCULTURAL E RELAÇÕES INTERGRUPAIS NA EUROPA: CONTRIBUTOS DOS ESTUDOS Culturais a da Psicologia Social}

\begin{abstract}
Resumo
Neste artigo discutem-se as contribuições dos Estudos Culturais e da Psicologia Social para as reflexões acerca dos desafios inerentes à promoção do diálogo intercultural na Europa, no contexto atual de relações intergrupais entre diversos Outros, propiciado por fatores como a intensificação dos fluxos migratórios e o avanço das tecnologias da informação e da comunicação. Para tanto, realizam-se articulações entre conceitos e categorias a partir de diferentes perspectivas teóricas nestes campos, de forma a associar discussões sobre processos identitários, alteridade, representações sociais, memória coletiva, assimetrias simbólicas, colonialidade do poder, do ser e do saber, a fim de (re)iniciar alguns debates sobre fenômenos complexos que se entrelaçam na construção do diálogo intercultural. Dessa forma, apresentam-se, ainda, diferentes concepções acerca dos conceitos de multiculturalismo e de interculturalidade, advogando-se a importância de uma perspectiva crítica na compreensão da interculturalidade, que a perceba como um projeto que parte das experiências dos "subalternos", a fim de buscar a transformação das estruturas sociais, institucionais e epistêmicas, (re)criando diferentes formas de ser, estar, de se relacionar, que impliquem não apenas o mero reconhecimento e tolerância de outras culturas, mas também a sua valorização, em diálogo e transformação mútuos.
\end{abstract}




\section{INTRODUCTION}

"Refugee crisis", Brexit, rise of hate speech in the public sphere and of far-right parties in Europe are phenomena that refer to the tensions, contradictions and complementarities between the local and the global (Beck, 2002), between the appreciation of cultural diversity and the exacerbated defence of an alleged authenticity. On the one hand, the appreciation of what is local and also the recognition of diversity within a given cultural context may function as possibilities to combat racist and homogenizing ideologies. On the other hand, they might also lead to localisms, to the (re)production of social stereotypes and discriminatory practices directed at different Others (Gros, 2002). Thus, as a result of the political, economic, technological and social transformations that took place mainly in the last century, we are living in a moment of pluralization of national and supranational identities (Hall, 2000), changes in the organization of societies and reformulations in the notion of citizenship (Martins, Sidoncha \& Bandeira, 2017). This conjuncture calls us to think about how we want and how we must (re)act: through the erection of walls or the construction of bridges? It is a moment when we must think about how Europe, as a superordinate group of belonging, places itself in this contemporary scenario: as a space of possibility of intercultural dialogue or as a space of intensification of power asymmetries and of mere tolerance of the different Others that are part of the region?

In this paper, we discuss the possible contributions of Cultural Studies and Social Psychology to these debates. In the context of Cultural Studies (e.g., Canclini, 1999/2010; Hall, 1996, 2000), we engage in a dialogue specially with the perspectives of Postcolonial Studies (e.g., Bhabha, 1990; Fanon, 1961/2004) and Decolonial Thinking (e.g., Maldonado-Torres, 2007; Quijano, 2005). Within Social Psychology, we consider mainly the Social Identity Theory (Tajfel, 1982a, 1982b, 1983) and the Social Representations Theory (Moscovici, 1961/2004), as well as discussions about collective memory (Licata \& Klein, 2005), intergroup relations involving national and supranational groups (Chryssochoou, 2000) and dynamics of acculturation (Berry, 2011).

The text is structured as follows: first, we draw some considerations about Cultural Studies and their different perspectives and developments in different regions; then we discuss the main convergences between Cultural Studies and Social Psychology, from the presentation of theoretical approaches and central concepts we use; finally, we discuss the concepts of multiculturalism and interculturality and point out possible paths for discussions on intergroup relations in contemporary Europe and the necessary conditions for it to become a place for intercultural dialogue. 


\section{Considerations about Cultural Studies}

Cultural Studies constitute a diverse and sometimes controversial scientific field of interdisciplinary nature, involving different areas of Human and Social Sciences, such as Anthropology, Communication Sciences, Education Sciences, Literary Studies, History, Geography, Psychology, Sociology, among others. They are a way of challenging previous narratives, which legitimize relations of power and domination, constituting possibilities of (re)constructing theoretical and methodological principles that help us study the differences and the diversity of our world (Hall, 2000). Therefore, more than a "closed" discipline, Cultural Studies stand as a project characterized by reflection, criticism and contestation of different concepts and categories, such as culture, identity, power, discourse, ideology, hegemony, among others, producing knowledge of a political nature, aimed at social transformation (Baptista, 2009; Barker, 2004).

After its emergence in England in the 1950s, Cultural Studies became more widespread in the 1960s and 1970s, mainly through works produced at the Centre for Contemporary Cultural Studies (CCCS) at the University of Birmingham, with authors such as Stuart Hall. Gradually, Cultural Studies began to encompass several areas of knowledge in the study of different aspects of intercultural relations. Hence especially in the late 1970s, Postcolonial Studies and Subaltern Studies also gained greater prominence (Neves, 2009). As a consequence, several investigations were developed on the relations of subordination and domination between different cultures involved in the processes of decolonization, mainly inspired by the work of authors such as Edward Said (1978/2007), Homi Bhabha (1990, 1994/2005), Frantz Fanon (1952/2008, 1961/2004) and Gayatri Spivak (1985/2010).

The studies developed based on these perspectives began to constitute new (theoretical and political) possibilities of analysing the world, in order to overcome certain dichotomies, such as the Western/Eastern polarity, as discussed by Said (Prysthon, 2004). Therefore, having these discussions as a starting point:

the concept of nation/state and pure national identity falls away, leaving space to a hybrid and mestizo identity. The "great narratives" are replaced by the history of postcolonial migrations and the cultural and political diaspora that characterize our present day. The "forgotten" raise their heads and begin to speak up, telling their stories of marginality and forgetfulness. Culture turns to "the margins" and becomes a "survival practice". (...) In short, colonialism increasingly appears as a key concept to decoding the present. (Neves, 2009, pp. 235-236)

In spite of the transformations arising from the diffusion of Postcolonial Studies and Subaltern Studies, in Latin America, for example, different authors (e.g., Grosfoguel, 2008; Lander, 2000; Maldonado-Torres, 2007; Mignolo, 2007; Quijano, 2005) have argued the need for decolonization of knowledge, so as to think of the world beyond European or other points of view, but under a contextualized look from Latin American colonial history. This perspective, known by different denominations, as Decolonial Option, 
Decolonial Theory or Decolonial Turn, embraces diverse concepts, among them, modernity/coloniality and coloniality of power, which we consider to be useful for reflecting on the possibilities of intercultural dialogue in Europe in current times.

With respect to the first concept, modernity/coloniality, as the name itself suggests, it means alerting to the imbrications between modernity and coloniality, the latter being an essential part of the former. Thus, as Porto-Gonçalves (2011, p. 42) argues, the subjugation of the native peoples in America, together with slavery and trafficking of black Africans who were brought to this continent, contributed to the consolidation of Europe's centrality, building the modern world-system alongside with coloniality, constituting itself, therefore, as a "modern-colonial world-system". Hence, the expression "modernity/coloniality", as Castro-Gómez (2005) argues, constitutes a re-elaboration of Wallerstein's idea of a world-system (1974), bringing, however, to the centre of the debate, the aspect of coloniality, as well as evidencing the patriarchal, capitalist, Eurocentric feature of this world-system (Grosfoguel, 2008).

The second concept, coloniality of power, was an idea proposed by Quijano (2005), according to which, even with the end of colonialism, colonial relations in the economic, political and social spheres did not end. Therefore, this term demarcates "a fundamental process of structuring the modern/colonial world-system, which articulates the peripheral places of the international division of labour with the global ethnic-racial hierarchy and with the enrolment of Third World migrants in the ethnic-racial hierarchy of global metropolitan cities" (Grosfoguel, 2008, p. 126). This concept was later expanded by different authors, such as Maldonado-Torres (2007) and Lander (2000), by also using the idea of coloniality as a coloniality of being and of knowledge. The association between these three forms of coloniality is visible, for example, during the process of European colonial domination, through which, in order to justify such domination, a knowledge about the Other was constructed, which allowed the (re)production of an image of this racialized colonized Other, so as to strip him/her of his/her condition of being.

After this brief characterization of Cultural Studies and some concepts derived from theoretical perspectives developed in different contexts, we will briefly discuss the main affinities between Cultural Studies and Social Psychology.

\section{Social Psychology and Cultural Studies}

Both the Cultural Studies and the approaches with which we work within Social Psychology attach great importance to interdisciplinarity and to ethical and political commitment in conducting the discussions and investigations carried out based on these perspectives. They also have in common the opposition to essentialism, to lack of historicism and to dichotomous thinking, highlighting the continuities and changes involved in the historical process of construction of reality, based on the interactions that individuals develop in their social world, in different historical and cultural contexts.

Despite the heterogeneity that exists with regard to possible analytical concepts and perspectives within Cultural Studies, Hall (1996) highlights the importance of the existence of common features that connect these perspectives and characterize this project. 
Nevertheless, this connection should also enable the recognition of the singularities of each context and of different "translations" that may exist. In this sense, Spink (2003), when writing the preface of the book Psicologia Social nos Estudos Culturais: perspectivas e desafios para uma nova psicologia social [Social Psychology in Cultural Studies: perspectives and challenges for a new Social Psychology], argues that this field is defined around two central concepts: identity and culture. The importance attributed to the cultural phenomenon and to identity processes is one of the central points of convergence between Social Psychology and Cultural Studies (Spink, 2003), as well as the other common characteristics mentioned above.

Regarding the concept of culture, this is a factor of proximity since psychosocial research in general aims to "perceive the intersections between social structures, social groups, culture, history and relations that people cultivate and that influence them as well" (Guareschi, Medeiros \& Bruschi, 2003, p. 32). One of the conceptions of culture that had an important influence in the initial process of development of Cultural Studies was the definition proposed by Williams (1958/2002), according to which culture is understood as something ordinary. This definition distances itself from existing elitist visions about this concept (Escosteguy, 2003). This perspective has contributed to the broadening of the concept of culture, since it also includes "the ways in which the rituals of everyday life, institutions and practices, alongside with the arts, constitute a cultural formation" (Escosteguy, 2003, pp. 61-62).

During the development of Cultural Studies, notably from works like Stuart Hall's, culture can be understood "both as a way of life (ideas, attitudes, languages, practices, institutions and power structures), and as a whole range of cultural practices (forms, texts, canons, architecture, mass produced goods)" (Guareschi et al., 2003, p. 34, author's emphasis). Given the inherent complexity of the concept of culture, therefore, it is important that different fields of knowledge are combined with the aim of providing a better understanding of the phenomena involved in the study of cultural processes, which can be achieved, for example, with the articulation between Cultural Studies and Social Psychology (Guareschi et al., 2003).

As for the concept of identity, the proximity between Social Psychology and Cultural Studies is also based on an anti-essentialist view of this concept, supporting the idea that identity is plural, the result of cultural and historical processes and that it is developed in relation to several Others (e.g., Bernardes \& Hoenisch, 2003; Tajfel, 1982b, 1983; Woodward, 2000). This idea corroborates with the concept of social identity, according to the Social Identity Theory, by understanding it as a relational process, and by comprehending that individuals can have as many identities as there are groups to which they feel they belong. According to this perspective, one works with the idea of a psychological group: belonging to a group presupposes emotional, evaluative and cognitive belonging, not just sharing common spaces (Tajfel, 1982a, 1982b, 1983).

In addition, the concept of social representation - understood as a type of knowledge from the common sense, which allows us to understand and explain reality, facilitating communicative processes (Moscovici, 1961/2004) - can also function as a dynamic 
field of studies on different issues, contributing to the articulation between different areas of knowledge (Cabecinhas, 2009), such as Social Psychology, Sociology, Cultural Studies, among others.

These are, therefore, some of the concepts, phenomena and processes that are intertwined in the articulation between Cultural Studies and Social Psychology. Such articulation becomes even more fruitful when we advance the discussions about the idea of interculturality, as we will do next.

\section{From multiculturalism to interculturality: contributions of Social Psychology and Cultural Studies}

The changes brought about by the processes of globalization, especially since the end of the $20^{\text {th }}$ century, mean that the concept of culture also underwent some modifications in order to include the notion of interculturality. Accordingly, Appadurai (2001) discusses the use of culture as an adjective, as the cultural, as a terrain of differences, contrasts and comparisons. Canclini (1999/2010), also using this conception proposed by Appadurai, complements that the cultural refers to processes by means of which

we imaginatively represent and institute the social, we conceive and manage relations with others, that is, differences, we ordain their dispersion and their incommensurability by means of a delimitation that floats between the order that enables the functioning of (local and global) society and the actors that open it to what is possible. (Canclini, 1999/2010, pp. 57-58)

Consequently, there is a tendency in several areas, such as Psychology, Sociology, Cultural Studies, among others, to talk about cultures, in the plural form, distancing oneself from the monoculturalism and monocultural epistemology that for a long time marked modernity, and changing the focus to multiculturalism (Veiga-Neto, 2003).

Regarding this last expression, it is a polysemic concept, and there may be different terms used to describe the situation of today's plural societies. For example, according to Hall (2000), there is a difference between the terms multicultural and multiculturalism, because while the first is qualifying and describes the characteristics of societies in which different cultures coexist, the second term, of substantive nature, concerns policies and/ or strategies that can be used to deal with problems of diversity from multicultural societies (Hall, 2000). Considering the polysemy of this concept, as discussed by several authors (e.g., André, 2012; Candau, 2008; Damázio, 2008; Gandin \& Hypolito, 2003; Hall, 2000; Lopes, 2012; Santos \& Nunes, 2003), there might exist different types of multiculturalism, according to the conceptualization that is adopted. For example, according to McLaren (1997), quoted in Damázio (2008), there are four types of multiculturalism: critical, conservative, liberal humanist and liberal left. Hall (2000), also considering McLaren's vision, lists six main types of multiculturalism: critical or "revolutionary", liberal, conservative, pluralistic, commercial and corporate (public or private)'.

\footnotetext{
' For the purposes of this paper, these concepts will not be deepened, since they would go beyond the purposes of the present reflection. For more information, see, for example: Damázio (2008); Hall (2000).
} 
Boaventura de Sousa Santos, in an interview with Gandin and Hypolito (2003), also discusses the importance of distinguishing between "conservative or reactionary forms of multiculturalism and the progressive and innovative ones" (Gandin \& Hypolito, 2003 , p. 11). Among the conservative forms, there is the colonial multiculturalism, in which there is no real recognition of other cultures, developing an assimilationist stance. Among the progressive forms, there is the emancipatory multiculturalism or decolonial interculturality, as the author has recently proposed (e.g., Santos, 2016), which is a postcolonial, anti-essentialist proposal, according to which "cultures are all internally differentiated and therefore it is as important to recognize cultures among each other, as it is important to recognize diversity within each culture and to allow resistance and difference within culture" (Gandin \& Hypolito, 2003, p. 13). However, as Santos points out in this interview, one must be aware to ensure that

we do not fall into the trap of accepting that recognition goes so far as to establish criteria of authenticity, which makes cultures become just cultures of testimony. And so, on women, on the women's movement and on discrimination against women, only women can talk; on black people and on discrimination against black people, only black people can speak. The idea of authenticity of testimony is, in my view, one of the forms that could lead to the development of a new cultural apartheid, and which could be achieved through excessive radicalism, because it would allow equality, but in separation. (Gandin \& Hypolito, 2003, p. 13)

Based on these considerations about the different uses of multiculturalism, Santos and Nunes (2003) list some criticisms referring to this concept. One of these criticisms is the very definition of culture that it uses, since there are also different concepts about it; another criticism refers to the idea of multiculturalism as being a Eurocentric concept that ignores the different forms that it can assume in different countries and regions of the world. Multiculturalism is also criticized as being a "denied form of racism" (Zizek, 1998, p. 22), linked to multinational capitalism (Zizek, 1998). Therefore, this is sometimes an "apolitical" and "descriptive" concept, from which "the appeal to the notion of 'tolerance' does not require active involvement with 'others' and reinforces the sense of superiority of whom speaks from a self-appointed place of universality" (Santos \& Nunes, 2003, p. 31).

Taking these criticisms into account, many authors propose the replacement of the term multiculturalism by interculturalism or interculturality (e.g., Candau, 2008; Damázio, 2008; Lopes, 2012). In this paper we use the term interculturality. However, also regarding this concept, there are different understandings. According to Walsh (2010, 2012), interculturality can be understood from three perspectives: relational, functional and critical. The relational perspective limits the conception of interculturality to contacts, to interpersonal relations, minimizing the tensions involved in these relations, i.e., the relations of power, domination, and coloniality. The functional perspective recognizes diversity and difference, but from a logic that is functional to the current neoliberal 
capitalist social system, i.e., aims to tolerate and/or incorporate the different Other to established social matrices, without questioning the causes of power asymmetries and social inequalities. Finally, the critical perspective questions the current social order, understanding interculturality as a process and a project, starting from the experiences of the "subalterns", of those who have been victims of xenophobia and racism, in order to seek the transformation of social, institutional and epistemic structures, (re)creating different ways of being and relating with others (Walsh, 2010, 2012), involving not only the mere recognition and tolerance of other cultures, but also their appreciation, in mutual dialogue and interaction (Canclini, 1999/2010). It is from this critical, decolonial perspective that we comprehend interculturality.

Accordingly, in order to understand the psychosocial processes involved in intercultural dialogue in contemporary plural societies, it is important to combine different knowledges, as we do in this paper, in order to provide a more contextualized and indepth analysis. In this sense, when discussing intercultural dialogue, we must also discuss identity and otherness, processes that are part of the relationship with the Other.

The relation with the Other, with otherness, with difference is a historical question and, currently, in the dialectic between local realities and globalizations, it reveals different contours and invites to greater understandings and reflections (Jovchelovitch, 2002). The development of the social identity of individuals and their social representations on different objects takes place within this relation with the Alter (individuals and/ or groups). This encounter with the Other involves contact with the unfamiliar (Moscovici, 2000/2010), with those Others who do not fit our cognitive, moral, aesthetic world patterns, those that obscure and confuse what once seemed so clear and simple: boundaries, limits, identifications, that is, they confuse, generate discomfort, estrangement (Bauman, 1997), hence destabilizing the existing and desired order (Joffe, 2002). However, this estrangement generated by the difference of the Other "surprises more to the extent that, in fact, the other is not so different, but a similar one that we cannot allocate" (Arruda, 2002, pp. 19-20). The attempt to situate the Others involves the understanding of alterity "as a psychosocial product and process" (Jodelet, 2002), which means that different processes are at play in the construction of social representations (Moscovici, 1961/2004) and social identities (Tajfel, 1982b, 1983), in order to organize the information received from the environment and anchor the unfamiliar into more familiar categories (Moscovici, 1961/2004).

These interactions with different Others become even more evident in the current context of globalization (André, 2012), which provokes changes not only in relation to economic aspects, such as the increase in the movement of goods, but also profound transformations in socio-cultural terms. Such process of globalization, when accompanied by other phenomena such as migrations, redefine national and identity borders (Beck, 2002; Hall, 2000), intensifying the pluralization of societies. In this sense, migrations enable the contact between people of different cultures and emphasize the process of social comparison, a basic mechanism to the development of social identity (Tajfel, 1982b, 1983). This process allows the emergence of different classifications and 
comparisons that individuals can establish between the various national and/or supranational groups with which they identify, thus enhancing the complexity of the distinctions between "us" and "them" (Chryssochoou, 2000).

The greater intercultural contact between different groups, such as what we witness, for example, in European context, also turns collective memories or social representations of history (Licata \& Klein, 2005; Liu \& Hilton, 2005) into more plural phenomena, challenging representations that are already known within the same group (Liu \& Hilton, 2005). This is the case, for instance, of supranational groups, such as the European Union. Although the different countries that comprise it have their specific characteristics and, although there are marked power asymmetries between them, it seems important that they share some elements in common within the social representations of this group's history and that political leaders take these representations into account when formulating policies that are commonly accepted among those involved and consistent with a common reality (Liu \& Hilton, 2005). Social Psychology and Cultural Studies have interesting theoretical resources to analyse the (re)constructions of these collective memories and the relations of coloniality that may be involved in these negotiations based on present-day intergroup relations.

In addition to these contributions to the analysis of identity and representational processes underlying intergroup relations, Social Psychology also has different models for the study of identity dynamics involved in relations between subgroups (e.g., European countries) and superordinate groups (e.g., Europe) (see, for example: Hornsey \& Hogg, 2000; Wenzel, Mummendey, \& Waldzus, 2007); and models for the study of intercultural strategies or acculturation strategies involving different groups, such as migrants and the host society (see: Berry, 2001, 2011).

The study of these relations between different Others becomes even more fruitful when associated with the conception of critical interculturality (Walsh, 2010, 2012), from the decolonial perspective, which we have previously discussed. Such a conception is important, above all, to overcome current challenges in the configuration of spaces of intercultural dialogue, such as those discussed, for example, by Oliveira (2017, p. 29). According to this author, in addition to the debates about the theoretical dimension of the concept of interculturality, it is necessary to consider its practical dimension, regarding the uses that are made of interculturality. In this sense, as the author argues, it has been recurrent in different European countries to adopt a "consumerist" logic of interculturality, in order to have a "marketization" of diversity and of some city centres, by means of incorporating migrants and their cultural traces to these ends.

Likewise, Cabecinhas and Cunha (2017) warned of the importance of going beyond the idea of diversity as something folkloric, for example, through the consumption of gastronomy, music and dance from different countries, and understand that, in order to have a dialogue with the Other, toleration of the Others or their assimilation is not enough, there must be real interaction and reciprocal transformations. Such context reminds us of the indispensability of reaffirming interculturality not only as the recognition of cultural diversity, but also as an egalitarian and respectful interaction among different Others living within a given territory. 


\section{ConcLusions}

In this paper we discussed possibilities that exist in the combined use of concepts and categories of Cultural Studies and Social Psychology for the analysis of intergroup relations and the construction of spaces of intercultural dialogue in contemporary Europe. We acknowledge, however, that other analyzes and interlocutions are possible, therefore, we did not intend to cover all the discussions about phenomena as complex as the ones we approached here, but rather to (re)initiate some discussions, which may lead us to so many other debates, in order to (re)create knowledges, techniques and institutions that allow the construction of bridges of dialogue between different Others in constant interaction not only in European context, but also in other parts of the world.

Therefore, we reaffirm the importance of intercultural dialogue as a challenge to be met (Cabecinhas \& Cunha, 2017), which is enhanced by listening to what Others have to say about themselves and what they think about the world. This listening can stimulate the development of greater openness to the plurality of cultures and knowledges, as well as greater empathy for the Other, in order to foster recognition, reciprocal exchanges and mutual transformation.

\section{FUNDING}

This work was supported by CAPES Foundation (Coordenação de Aperfeiçoamento de Pessoal de Nível Superior) - Ministry of Education of Brazil, through a PhD scholarship (Reference number: 1690/13-2) provided to the first author.

Translation: Julia Alves Brasil

\section{REFERENCES}

André, J. M. (2012). Interpretações do mundo e multiculturalidade: incomensurabilidade e diálogo entre culturas. In J. M. André (Ed.), Multiculturalidade, identidades e mestiçagem: o diálogo intercultural nas ideias, na política, nas artes e na religião (pp. 73-104). Coimbra: Palimage.

Appadurai, A. (2001). La modernidad desbordada: dimensiones culturales de la globalización. Buenos Aires: Ediciones Trilce.

Arruda, A. (2002). O ambiente natural e seus habitantes no imaginário brasileiro. In A. Arruda (Ed.), Representando a alteridade (pp. 17-46). Petrópolis: Vozes.

Baptista, M. M. (2009). Estudos culturais: o quê e o como da investigação. Carnets - Cultures littéraires: nouvelles performances et développement, [n spécial], 451-461. Retrieved from http://revistas.ua.pt/index. php/Carnets/article/view/466/422

Barker, C. (2004). The SAGE dictionary of cultural studies. London: Sage Publications.

Bauman, Z. (1997). The making and unmaking of strangers. In P. Werbner \& T. Modood (Eds.), Debating cultural hybridity: multi-cultural identities and the politics of anti-racism (pp. 46-57). London and New Jersey: Zed Books. 
Beck, U. (2002). The cosmopolitan society and its enemies. Theory, Culture Q Society, 19(1-2), 17-44. https:// doi.org/10.1177/026327640201900101

Bernardes, A. G. \& Hoenisch, J. C. D. (2003). Subjetividade e identidades: possibilidades de interlocução da Psicologia Social com os Estudos Culturais. In N. M. F. Guareschi \& M. E. Bruschi (Eds.), Psicologia Social nos Estudos Culturais: perspectivas e desafios para uma nova Psicologia Social (pp. 95-126). Petrópolis: Vozes.

Berry, J. W. (2001). A psychology of immigration. Journal of Social Issues, 57(3), 615-631. https://doi. org/10.1111/0022-4537.00231

Berry, J. W. (2011). Integration and multiculturalism: ways towards social solidarity. Papers on Social Representations, 20, 2.1-2.21. Retrieved from http://psych.lse.ac.uk/psr/PSR2011/20_02.pdf

Bhabha, H. K. (1990). Nation and narration. London: Routledge.

Bhabha, H. K. (1994/2005). O local da cultura. Belo Horizonte: UFMG.

Cabecinhas, R. (2009). Investigar representações sociais: metodologias e níveis de análise. In M. M. Baptista (Ed.), Cultura: metodologias e investigação (pp. 51-66). Lisboa: Ver o Verso Edições.

Cabecinhas, R. \& Cunha, L. (2017). Introdução: da importância do diálogo ao desafio da interculturalidade. In R. Cabecinhas \& L. Cunha (Eds.), Comunicação intercultural: perspectivas, dilemas e desafios (pp. 7-12). V.N. Famalicão: Húmus.

Canclini, N. G. (1999/2010). A globalização imaginada. São Paulo: Iluminuras.

Candau, V. M. (2008). Direitos humanos, educação e interculturalidade: as tensões entre igualdade e diferença. Revista Brasileira de Educação, 13(37), 45-56. http://dx.doi.org/10.1590/ S1413-24782008000100005

Castro-Gómez, S. (2005). Ciencias sociais, violencia epistêmica e o problema da "invencao do outro". In E. Lander (Ed.), A colonialidade do saber: eurocentrismo e ciências sociais. Perspectivas latino-americanas (pp. 8o-87). Ciudad Autónoma de Buenos Aires: Colección Sur Sur, CLACSO.

Chryssochoou, X. (2000). Memberships in a superordinate level: re-thinking European Union as a multinational society. Journal of community Q Applied Social Psychology, 10(5), 403-420. https://doi. org/10.1002/1099-1298(200009/10)10:5<403::AID-CASP597>3.0.CO;2-4

Damázio, E. S. P. (2008). Multiculturalismo versus interculturalismo: por uma proposta intercultural do Direito. Desenvolvimento em Questão, 6(12), 63-86. https://doi.org/10.21527/2237-6453.2008.12.63-86

Escosteguy, A. C. D. (2003). Os Estudos Culturais e a constituição de sua identidade. In N. M. F. Guareschi \& M. E. Bruschi (Eds.), Psicologia Social nos Estudos Culturais: perspectivas e desafios para uma nova Psicologia Social (pp. 51-74). Petrópolis: Vozes.

Fanon, F. (1961/2004). The wretched of the Earth. New York: Grove Press.

Fanon, F. (1952/2008). Pele negra, máscaras brancas. Salvador: EDUFBA.

Gandin, L. A. \& Hypolito, Á. M. (2003). Dilemas do nosso tempo: globalização, multiculturalismo e conhecimento (entrevista com Boaventura de Sousa Santos). Currículo sem fronteiras, 3(2), 5-23. Retrieved from http://www.curriculosemfronteiras.org/volziss2articles/boaventura.pdf

Gros, C. (2002). América Latina: identidade o mestizaje? La nación em juego. Desacatos, 10, 127-147. Retrieved from http://www.redalyc.org/articulo.oa?id=13901009 
Grosfoguel, R. (2008). Para descolonizar os estudos de economia politica e os estudos pós-coloniais: transmodernidade, pensamento de fronteira e colonialidade global. Revista Crítica de Ciências Sociais, 80, 115-147. Retrieved from https://dialnet.unirioja.es/servlet/articulo?codigo=2763903

Guareschi, N. M. F., Medeiros, P. F. \& Bruschi, M. E. (2003). Psicologia Social e Estudos Culturais: rompendo fronteiras na produção do conhecimento. In N. M. F. Guareschi, \& M. E. Bruschi (Eds.), Psicologia Social nos Estudos Culturais: perspectivas e desafios para uma nova psicologia social (pp. 23-49). Petrópolis: Vozes.

Hall, S. (1996). Cultural studies and the politics of internationalization: an interview with Stuart Hall by Kuan-Hsing Chen. In D. Morley, \& K-H Chen (Eds.), Stuart Hall - critical dialogues in cultural studies (pp. 261-274). New York/London: Routledge.

Hall, S. (2000). Conclusion: the multi-cultural question. In B. Hesse (Ed.), Un/settled multiculturalisms: diasporas, entanglements, 'transruptions' (pp. 209-241). London: Zed Books.

Hornsey, M. J. \& Hogg, M. A. (2000). Assimilation and diversity: an integrative model of subgroup relations. Personality and Social Psychology Review, 4(2),143-156. https://doi.org/10.1207/S15327957PSPRo402_03

Jodelet, D. (2002). A alteridade como produto e processo psicossocial. In A. Arruda (Ed.), Representando a alteridade (pp. 47-67). Petrópolis: Vozes.

Joffe, H. (2002). Degradação, desejo e "o outro". In A. Arruda (Ed.), Representando a alteridade (pp. 109-128). Petrópolis: Vozes.

Jovchelovitch, S. (2002). Re(des)cobrindo o outro - para um entendimento da alteridade na teoria das representações sociais. In A. Arruda (Ed.), Representando a alteridade (pp. 69-82). Petrópolis: Vozes.

Lander, E. (Ed.) (2000). La colonialidad del saber: eurocentrismo y ciencias sociales. Perspectivas latinoamericanas. Buenos Aires, Argentina: Consejo Latinoamericano de Ciencias Sociales. Retrieved from http://bibliotecavirtual.clacso.org.ar/clacso/sur-sur/20100708034410/lander.pdf

Licata, L. \& Klein, O. (2005). Regards croisés sur un passé commun: anciens colonisés et anciens coloniaux face à l'action belge au Congo. In M. Sanchez-Mazas \& L. Licata (Eds.), L'Autre: regards psychosociaux (pp. 241-277). Saint-Martin d'Hères: Presses Universitaires de Grenoble.

Liu, J. H. \& Hilton, D. (2005). How the past weighs on the present: towards a social psychology of histories. British Journal of Social Psychology, 44, 537-556. https://doi.org/10.1348/014466605X27162

Lopes, A. M. D. (2012). Da coexistência à convivência com o outro: entre o multiculturalismo e a interculturalidade. Revista Interdisciplinar de Mobilidade Humana, 38, 67-81. http://dx.doi.org/10.1590/ S1980-85852012000100005

Maldonado-Torres, N. (2007). Sobre la colonialidad del ser: contribuciones al desarrollo de un concepto. In S. Castro-Gómez \& R. Grosfoquel (Eds.), El giro decolonial. Reflexiones para una diversidad epistémica más allá del capitalismo global (pp. 127-167). Bogotá: Siglo del Hombre.

Martins, M. L., Sidoncha, U. \& Bandeira, M. (2017). Nota introdutória - Estudos Culturais, cidadania e democracia. Revista Lusófona de Estudos Culturais, 4(2), 7-11. Retrieved from http://hdl.handle. net $/ 1822 / 54186$

Mignolo, W. D. (2007). La idea de América Latina: la herida colonial y la opción decolonial. Barcelona: Editorial Gedisa.

Moscovici, S. (1961/2004). La psychanalyse son image et son public. Paris: Presses Universitaires de France.

Moscovici, S. (2000/2010). O fenômeno das representações sociais. In G. Duveen (Ed.), Representações sociais: investigações em Psicologia Social (pp. 29-109). Petrópolis: Vozes. 
Neves, R. C. (2009). Os Estudos Pós-Coloniais: um paradigma de globalização. Babilónia - Revista Lusófona de Línguas, Culturas e Tradução, 6/7, 231-239. Retrieved from http://hdl.handle.net/10437/2111

Oliveira, N. (2017). Do multiculturalismo ao interculturalismo: um novo modo de incorporação da diversidade cultural? Revista Ambivalência, 5(9), 10-35. https://doi.org/10.21665/2318-3888.v5n9p10-35

Porto-Gonçalves, C. W. (2011). Abya Yala, el descubrimiento de América. In N. Giarraca (Ed.), Bicentenarios (otros), trasiciones y resistencias (pp. 39-46). Buenos Aires: Uma Ventana.

Prysthon, A. (2004). Interseções da teoria crítica contemporânea: estudos culturais, pós-colonialismo e comunicação. Revista e-Compós, 1, 1-19. Retrieved from https://revistas.ufrj.br/index.php/eco_pos/ article/view/1119

Quijano, A. (2005). Colonialidade do poder, eurocentrismo e América Latina. In E. Lander (Ed.), A colonialidade do saber: eurocentrismo e ciências sociais. Perspectivas latino-americanas (pp. 227-278). Ciudad Autónoma de Buenos Aires: Colección Sur Sur, CLACSO.

Said, E. W. (1978/2007). Orientalismo - o Oriente como invenção do Ocidente. São Paulo: Companhia de Bolso.

Santos, B. S. (2016). A difícil democracia: reinventar as esquerdas. São Paulo: Boitempo.

Santos, B. S. \& Nunes, J. A. (2003). Introdução: para ampliar o cânone do reconhecimento, da diferença e da igualdade. In B. S. Santos (Ed.), Reconhecer para libertar: os caminhos do cosmopolitismo multicultural (pp. 25-68). Rio de janeiro: Civilização Brasileira.

Spink, M. J. P. (2003). Prefácio. In N. M. F. Guareschi \& M. E. Bruschi (Eds.), Psicologia Social nos Estudos Culturais: perspectivas e desafios para uma nova psicologia social (pp. 9-19). Petrópolis: Vozes.

Spivak, G. C. (1985/2010). Pode o subalterno falar? Belo Horizonte: Editora da UFMG.

Tajfel, H. (1982a). Comportamento intergrupo e psicologia social da mudança. In A. F. Barroso, B. M. Silva, J. Vala, B. M. Monteiro \& M. H. Castro (Eds.), Mudança social e psicologia social (pp. 13-24). Lisboa: Livros horizonte.

Tajfel, H. (1982b). Grupos humanos e categorias sociais. Vol. 1. Lisboa: Livros Horizonte.

Tajfel, H. (1983). Grupos humanos e categorias sociais. Vol. 2. Lisboa: Livros Horizonte.

Veiga-Neto, A. (2003). Cultura, culturas e educação. Revista Brasileira de Educação, 23, 5-15. http://dx.doi. org/10.1590/S1413-24782003000200002

Wallerstein, I. (1974). The modern world system. Vol. 1. Nova lorque: Academic Press.

Walsh, C. (2010). Interculturalidad crítica y educación intercultural. In J. Viaña, L. Tapia \& C. Walsh (Eds.), Construyendo interculturalidad crítica (pp. 75-96). La Paz: Instituto Internacional de Integración, Convenio Andrés Bello.

Walsh, C. (2012). Interculturalidad crítica y (de)colonialidad. Ensayos desde Abya Yala. Quito: Editorial Abya-Yala, Serie Pensamiento decolonial.

Wenzel, M., Mummendey, A. \& Waldzus, S. (2007). Superordinate identities and intergroup conflict: the ingroup projection model. European Review of Social Psychology, 18(1), 331-372. https://doi. org/10.1080/10463280701728302

Williams, R. (1958/2002). Culture is ordinary. In B. Highmore (Ed.), The everyday life reader (pp. 91-100). London: Routledge. 
Woodward, K. (2000). Identidade e diferença: uma introdução teórica e conceitual. In T. T. Silva (Ed.), Identidade e diferença: a perspectiva dos Estudos Culturais (pp. 7-72). Petrópolis: Vozes.

Zizek, S. (1998). Multiculturalismo o la lógica cultural del capitalismo multinacional. In F. Jameson \& S. Zizek (Eds.), Estudios culturales. Reflexiones sobre el multiculturalismo (pp. 137-188). Buenos Aires: Paidós.

\section{BIOGRAPHICAL NOTES}

Julia Alves Brasil holds a PhD in Cultural Studies at University of Minho/Portugal. Master and bachelor's degrees in Psychology at Federal University of Espirito Santo (UFES)/Brazil. Collaborator researcher at Communication and Society Research Centre (CECS)/University of Minho. Postdoctoral researcher in Social Psychology at UFES.

ORCID: https://orcid.org/0000-0003-0445-1207

Email: juliaalvesbrasil@gmail.com

Address: Fernando Ferrari Avenue, 514, Goiabeiras, Vitória - ES, Brasil. Postal code: 29075-910

Rosa Cabecinhas holds a PhD in Social Psychology of Communication. She is Associate Professor at the Social Sciences Institute of University of Minho, researcher at the Communication and Society Research Centre, and Head of the Cultural Studies Doctoral Program.

ORCID: https://orcid.org/oooo-0oo2-1491-3420

Email: cabecinhas@ics.uminho.pt

Address: Institute of Social Sciences, University of Minho Gualtar Campus, 4710057, Braga, Portugal

* Submitted: 14/09/2018

*Accepted:18/12/2018 